\title{
PEMBERIAN IZIN POLIGAMI OLEH PENGADILAN AGAMA DI INDONESIA
}

\author{
Fitri Rafianti \\ Fakultas Sosial Sains Universitas Pembangunan Panca Budi \\ Jl. Jend.Gatot Subroto, Km.4,5 Sei Sikambing, Medan - Sumatera Utara \\ Email: fitrirafianti@gmail.com
}

\begin{abstract}
Abstrak
Poligami adalah masalah yang tidak ada habisnya untuk membahas munculnya hukum fiqh klasik yang tampaknya memberikan kesempatan kepada suami dalam poligami, bergeser ke aturan dan hukum produk negara yang tidak hanya membatasi dan menyulitkan, tetapi bahkan melarang dan mengkategorikan masalah di sekitar keluarga hukum sebagai tindakan ilegal. Di sisi lain, ada pemahaman sewenang-wenang tentang poligami dalam Hukum Keluarga Islam di Indonesia. Sifat poligami yang berkembang dalam masyarakat yang tidak menguntungkan perempuan, oleh karena itu, dari masalah poligami dan hubungannya dengan pelembagaan hukum, penting untuk diketahui bahwa aturan peradaban individu telah memasuki ranah hukum publik, sebagai salah satu gambar dinamisasi dalam hukum Islam Penelitian ini adalah pendekatan yuridis normatif yang dilakukan dengan menganalisis masalah yang ada dalam penelitian ini melalui pendekatan terhadap prinsip-prinsip hukum, serta mengacu pada normanorma hukum yang terkandung dalam undang-undang dan peraturan yang berkaitan dengan judul ini penelitian.
\end{abstract}

\section{Kata Kunci: Izin, Poligami, Pengadilan, Agama}

\section{Abstract}

Polygamy is an inexhaustible problem for discussing the rise of classical fiqh law that seems to give an opportunity to a husband in polygamy, shifts to the rules and laws of state products that not only limit and complicate, but even prohibit and categorize a problem around family law as an illegal act. On the other hand, there is an arbitrary understanding of polygamy in Islamic Family Law in Indonesia. The nature of polygamy that develops in society that does not benefit women, therefore, from the issue of polygamy and its relation to institutionalization of law it becomes important to work out that individual civilization rules have entered the realm of public law, as one of the images dynamized in Islamic law This research is a normative juridical approach that is carried out by analyzing the problems that exist in this study through approaches to legal principles, as well as referring to legal norms contained in the laws and regulations relating to the title of this research.

Keywords: Permission, Polygamy, Judicial, Religion

\section{PENDAHULUAN}

Poligami merupakan bagian dari perkawinan dalam lingkup hukum perdata Islam (al Ahwal al-Syakhshiyyah). Dalam praktiknya, persoalan poligami merupakan topik yang senantiasa hangat dibicarakan. Disamping itu, beranjak dari hukum fiqh klasik yang terkesan memberi peluang kepada seorang suami berbuat sewenang-wenang dalam berpoligami, beralih kepada aturan-aturan dan hukum produk negara yang tidak saja membatasi dan mempersulit, namun bahkan melarang dan mengkategorikan suatu masalah seputar hukum 
Jurnal Ilmu Hukum

FAKULTAS HUKUM UMSU
Pemberian Izin Poligami...(Fitri Rafianti)

Volume 4 Nomor 1, Januari-Juni 2019, 1-15

DOI: https://doi.org/10.30596/dll.v4i1.3167

keluarga sebagai perbuatan melanggar hukum. Kaitan dengan hal tersebut, dalam hal ini, yang ingin dilihat secara komprehensif tentang peraturan perundang-undangan yang diterapkan pada negara muslim modern, terutama Indonesia dalam mengatur poligami yang sesungguhnya, dalam rangka membangun sebuah kondisi yang sangat konstruktif bagi upaya terbentuknya masyarakat tertib hukum. Di sisi lain, adanya pemahaman yang semena-mena tentang poligami dalam Hukum Keluarga Islam diIndonesia.

Hakikat poligami yang berkembang di masyarakat yang tidak menguntungkan kaum wanita. Oleh sebab itu, dari persoalan poligami dan kaitannya dengan pelembagaan hukum adalah menjadi penting untuk digarap mengingat bahwa aturan keperdataan individual telah masuk ke dalam ranah hukum publik, sebagai salah satu citra dinamisasi dalam hukum Islam, khususnya hukum keluarga Negara Muslim modern. Artinya, negara berkepentingan untuk mengatur poligami demi terwujudnya keutuhan masyarakat yang taat hukum. Dengan itu, maka praktik poligami yang diatur dalam hukum keluarga Islam di Indonesia dan merupakan langkah yang positif dalam mengatur ketertiban perkawinan di Indonesia.

\section{METODE PENELITIAN}

Penelitian ini adalah penelitian hukum normatif. Objek penelitian ini adalah norma hukum yang terwujud dalam kaidah-kaidah hukum formil dan materil dalam peraturan perundang-undangan yang terkait dengan Pemberian izin Poligami oleh Pengadilan Agama Di Indonesia. Penelitian hukum adalah suatu proses untuk menemukan aturan hukum, prinsip-prinsip hukum, maupun doktrin-doktrin hukum guna menjawab isu hukum yang dihadapi (Peter Mahmud Marzuki, 2008, h. 35). Jenis penelitian yang digunakan dalam penelitian ini adalah penelitian yuridis normatif yaitu pendekatan yang dilakukan dengan menganalisis permasalahan yang ada dalam penelitian ini melalui pendekatan terhadap asasasas hukum (Soerjono Soekanto, 2001, h. 14), serta mengacu kepada norma-norma hukum yang terdapat dalam peraturan perundang-undangan yang berkaitan dengan judul penelitian ini. Penelitian normatif mengacu pada teori-teori, doktrin-doktrin, norma-norma dan asas-asas serta kaidah-kaidah hukum yang terdapat dalam Peraturan Perundang-Undangan maupun di dalam putusan pengadilan (Johny Ibrahim, 2008, h. 282). Sifat penelitian ini adalah deskriptif analitis yaitu menggambarkan dan menguraikan serta sekaligus menganalisis mengenai faktafakta melalui pendekatan Peraturan Perundang-Undangan (statuta approach) (Peter Mahmud Marzuki, 2008, h. 96).

\section{PEMBAHASAN}

\section{Prosedur Pemberian Izin Poligami Dalamkompilasi Hukum Islam}

Di dalam Kompilasi Hukum Islam (KHI) berdasarkan Instruksi Presiden Republik Indonesia Nomor 1 Tahun 1991, Juga terdapat pengaturan tentang persyaratan poligami, yang ketentuannya dimuat dalam pasal 55 sampai 59 .KHI menekankan bahwa syarat berpoligami adalah mampu berbuat adil jika syarat tersebut tidak terpenuhi maka suami dilarang berpoligami. Selain KHI syari;at Islam memberikan syarat-syarat bagi pria yang hendak 
DE LEGA LATA

Jurnal Ilmu Hukum

FAKULTAS HUKUM UMSU
Pemberian Izin Poligami...(Fitri Rafianti)

Volume 4 Nomor 1, Januari-Juni 2019, 1-15

DOI: https://doi.org/10.30596/dll.v4i1.3167

berpoligami yaitu : (Musfir Al-jahrani, 1997, h. 39)

a. Jumlah Wanita yang dikawini tidak boleh lebih 4 orang.

b. Sanggup berlaku adil terhadap semua istrinya.

c. Wanita yang akan dikawini seyogyanya adalah wanita yang mempunyai anak yatim.

d. Tidak dibolehkan dengan wanita yang mempunyai hubungan saudara sepersusuan dengan istrinya.

e. Tidak bermaksud hendak mempermainkan atau menganiaya wanita yang akan dikawininya.

Hal tersebut diatas dimaksudkan untuk memberikan landasan dan pondasi yang kuat untuk membatasi keburukan poligami yang terjadi di masyarakat yang melakukan poligami. Tujuannya adalah untuk memelihara kemuliaan mereka yang dulu terabaikan karena poligami tanpa ikatan.

Berdasarkan hal diatas salah satu persyaratan yang sangat berat adalah berlaku adil kepada semua istri dan anak-anaknya sementara yang dimaksud dengan adil adalah tidak ada pembatasan atau kriteria yang tegas baik menurut peraturan perundang-undangan maupun peraturan syari;at sendiri. Mengingat bahwa perkawinan poligami sering menyebabkan kemelut dalam rumah tangga maka banyak pihak yang menentang pelaksanaannya, demikian pula ketentuan dalam UU Perkawinan yang sebenarnya tidaklah membolehkan seorang pria beristri lebih dari satu, kecuali karena adanya alasan -alasan tertentu. Pasal 3 ayat 1 UndangUndang Nomor 1 Tahun 1974 tentang Perkawinan, telah menegaskan bahwa seorang pria hanya boleh mempunyai seorang istri dan sebaliknya seorang wanita hanya boleh mempunyai seorang suami.

Di dalam perundang-undang di Indonesia, persoalan izin dalam poligami diatur dalam Kompilasi Hukum Islam (KHI) pada pasal 56, 57, 58 dan 59, sementara dalam UndangUndang Nomor 1 Tahun 1974 tentang Perkawinan diatur dalam pasal 3 dan pasal 4. Menurut Kompilasi Hukum Islam, suami yang ingin beristeri lebih dari satu orang, maka ia harus mendapat izin dari Pengadilan Agama.

Artinya, perkawinan poligami dilakukan tanpa izin Pengadilan Agama tidak mempunyai kekuatan hukum. Hal serupa juga ditegaskan dalam Undang-Undang Perkawinan Nomor 1 Tahun 1974. Namun, mengenai prosedur pengajuan untuk mendapatkan izin dari pengadilan, Kompilasi Hukum Islam tidak membicarakan hal tersebut, tapi secara rinci dikupas oleh Undang-undang Perkawinan Nomor 1 Tahun 1974, yaitu tentang, dan ada atau tidak adanya jaminan bahwa suami akan berlaku adil terhadap isteri-isteri dan anak-anaknya. Maka jika dilapangan ditemukan ada pelaku poligami yang tidak mendapat izin dari istri sebelumnya dapat melakukan poligami maka keberadaan dokumen yang disertakan kepada pihak pengadilan agama harus diperiksa kembali mengenai keasliannya, karena seorang yang mempunyai keinginan yang tidak dapat dipenuhi oleh istrinya karena ia tidak memenuhi kategori yang dapat melakukan poligami biasanya ia akan melakukan berbagai cara untuk memuluskan rencananya.

KHI Pasal 56 ayat 1 KHI Pasal 56 ayat 3 "Perkawinan yang dilakukan dengan isteri 
Jurnal Ilmu Hukum

FAKULTAS HUKUM UMSU
Pemberian Izin Poligami...(Fitri Rafianti)

Volume 4 Nomor 1, Januari-Juni 2019, 1-15

DOI: https://doi.org/10.30596/dll.v4i1.3167

kedua, ketiga atau keempat tanpa izin dari Pengadilan Agama, tidak mempunyai kekuatan hukum". Lebih detailnya di dalam KHI Pasal 41 Peraturan Pemerintah Nomor 9 Tahun 1975 tentang Pelaksanaan Undang-Undang Nomor 1 Tahun 1974 tentang Perkawinan:

a. Ada atau tidak adanya alasan yang memungkinkan seorang suami kawin lagi, ialah:

1) Bahwa isteri tidak dapat menjalankan kewajibannya sebagai isteri

2) Bahwa isteri mendapat cacat badan atau penyakit yang tidak dapat disembuhkan.

3) Bahwa isteri tidak dapat melahirkan keturunan.

4) Ada atau tidak adanya persetujuan dari isteri baik persetujuan lisan maupun tertulis apabila persetujuan itu merupakan persetujuan merupakan persetujuan lisan, persetujuan itu harus diucapkan di depan sidang pengadilan

5) Ada atau tidak adanya kemampuan suami untuk menjamin keperluan hidup isteriisteri dan anak-anak dengan memperlihatkan surat keterangan mengenai penghasilan suami yang ditandatangi oleh bendahara tempat bekerja, atau

6) Surat keterang pajak penghasilan; atau

7) Surat keterangan lain yang dapat diterima oleh Pengadilan artinya jika persyaratan diatas tidak dapat dipenuhi maka perkawinan yang dilangsungkan adalah perkawinan sirri dan tidak memiliki kekuatan hukum di indonesia dan hak haknya sebagai warga negara yang berhubungan dengan hukum kekeluargaan tidak dapat dipenuhi.

b. Ada atau tidak adanya jaminan bahwa suami akan berlaku adil

Selanjutnya dalam melakukan pemerikasan perkara, Pengadilan memanggil dan mendengar isteri yang bersangkutan. Biasanya pemeriksaan pengadilan tersebut dilakukan oleh hakimdalam waktu selambat-lambatnya 30 hari setelah diterimanya surat permohonan beserta lampiranlampirannya.Apabila pengadilan berpendapat bahwa seorang suami yang ingin beristeri lebih dari satu cukup alasanalasannya, maka pengadilan menetapkan putusannya berupa pemberian izin kepada suami tersebut untuk beristeri lebih dari satu orang isteri.

Di Indonesia, ada kelompok orang tertentu dalam hal pemberlakuan hukum keluarga Islam terutama dalam persoalan poligami. Kelompok itu adalah warga negara Indonesia yang mengabdi pekerjaan mereka kepada negara, yaitu Pegawai Negeri Sipil (PNS). Seorang PNS yang akan berpoligami, wajib memperoleh izin lebih dahulu dari Pejabat, dan PNS wanita tidak diizinkan menjadi istri yang kedua/ketiga/keempat. Isteri-isteri dan anak-anak mereka dengan pernyataan atau janji dari suami yang dibuat dalam bentuk yang ditetapkan untuk itu.

Peraturan Pemerintah Nomor 9 Tahun 1975 tentang Pelaksanaan Undang-Undang Nomor 1 Tahun 1974 tentang Perkawinan Pasal 41 jo. Pasal 42 jo. Pasal 43 "Apabila Pengadilan berpendapat bahwa cukup alasan bagi pemohon untuk beristeri lebih dari seorang, maka pengadilan memberikan putusannya yang berupa izin untukberisteri lebih dari seorang”. Pasal 4 dan 7 dan Peraturan Pemerintah Nomor 45 Tahun 1990 Tentang Perubahan Atas Peraturan Pemerintah Nomor 10 Tahun 1983 tentang Izin Perkawinan Perkawinan dan Perceraian Bagi Pegawai Negeri Sipil "Pegawai Negeri Sipil pria yang akan beristri lebih dari seorang, wajib memperoleh izin lebih dahulu dari pejabat". Peraturan Pemerintah Nomor 10 Tahun 1983 tentang Izin Perkawinan Perkawinan dan Perceraian Bagi Pegawai Negeri Sipil 
Jurnal Ilmu Hukum

FAKULTAS HUKUM UMSU
Pemberian Izin Poligami...(Fitri Rafianti)

Volume 4 Nomor 1, Januari-Juni 2019, 1-15

DOI: https://doi.org/10.30596/dll.v4i1.3167

ayat 2 PP Nomor 45 Tahun 1990 Perubahan Nomor 2 ayat 2 "Pegawai Negeri Sipil wanita tidak diizinkan untuk menjadi istri yang kedua/ketiga/keempat"”.

Menurut Mohammad Daud Ali, dalam rangka mengatasi masalah ini, izin pengadilan agama tidak boleh dianggap sebagai syarat sah perkawinan kedua. Cukuplah dianggap sebagai syarat yang harus dipenuhi dalam rangka melindungi kaum wanita dan anak-anak. Di samping itu, untuk mengurangi poligami dapat juga ditempuh cara dengan memberikan sanksi pidana bagi suami yang menikah untuk kedua kalinya, tanpa melalui izin pengadilan agama. Jadi tidak hanya denda Rp. 7.500,- sebagaimana yang terdapat dalam PP pelaksanaan UU Perkawinan pasal 45 ayat 1a. mengenai batasan jumlah bagi suami yang ingin berpoligami, tampaknya KHI konsisten dengan ayat al-Qur'an surah aN- Nisa'/4:3 yang hanya memberikan alasan sampai empat orang dalam waktu yang bersamaan. Pentingnya untuk dicatat ketentuan hukum yang mengatur tentang pelaksanaan poligami seperti lelah diuraikan di atas mengikat semua pihak, pihak yang akan melangsungkan poligami dan pegawai pencatat perkawinan.

Apabila mereka melakukan pelanggaran terhadap ketentuan-ketentuan pasal di atas dikenakan sanksi pidana. Melihat prosedur pelaksanaan Poligami di atas tampak jelas semangat kehati-hatian yang dikandung oleh undang-undang. Ini pulalah yang membedakannya dengan fiikih Islam yang memberikan kelonggaran berpoligami. Sebenarnya aturan-aturan yang sangat rinci tersebut dimaksudkan agar izin poligami tersebut tidak menimbulkan akses negatif dan tidak menimbulkan kemafsadatan bagi pihak-pihak yang berkepentingan.

Sebaliknya yang ingin diwujudkan dalam aturan-aturan tersebut terciptanya kemaslahatan bagi semua pihak baik bagi istri/istri-istri, suami dan anak-anak. Ahmad Safwat mendasarkan keharusan izin pengadilan bagi orang yang akan melakukan poligami, dengan alasan bahwa polgami melahirkan kemudaratan kepada masyarakat secara umum, dan lebih khusus kepada istri dan keluarga secara keseluruhan.

\section{Persyaratan Poligami Dalam Perundang-Undangan Islam Di Indonesia}

Izin beristri lebih dari seorang, termasuk PNS, hanya dapat diberikan apabila memenuhi sekurang-kurangnya salah satu syarat alternatif, dan tiga syarat komulatif. Adapun syaratsyarat alternatif dimaksud adalah:

a. Isteri tidak dapat menjalankan kewajibannya sebagai isteri;

b. Isteri mendapat cacat badan atau penyakit yang tidak dapat disembuhkan; atau

c. Isteri tidak dapat melahirkan keturunan,

Sedang syarat kumulatif adalah:

a. Ada persetujuan tertulis dari isteri-isteri;

b. Adanya kepastian bahwa suami mampu menjamin keperluan hidup isteri dan anak-anak mereka; dan

c. Ada jaminan tertulis bahwa suami akan berlaku adil terhadap istri-istri dan anak-anaknya.

Keadilan yang diperlukan dalam poligami adalah keadilan material seperti yang 
Jurnal Ilmu Hukum

FAKULTAS HUKUM UMSU
Pemberian Izin Poligami...(Fitri Rafianti)

Volume 4 Nomor 1, Januari-Juni 2019, 1-15

DOI: https://doi.org/10.30596/dll.v4i1.3167

berkenaan dengan tempat tinggal, pakaian, makanan, minum, perumahan dan hal-hal yang bersifat kebutuhan material istri (Ali Ahmad Al-Jurjawi, 10-12). Justru disinilah masalahnya, para ulama fikih cenderung memahami keadilan di sini secara kuantitatif yang bisa diukur dengan angka-angka, padahal sebagaimana yang difatwakan Abduh, keadilan yang disyaratkan al-Qur'an adalah keadilan yang bersifat kualitatif seperti kasih sayang, cinta, perhatian dan semuanya tidak bisa diukur dengan angkaangka.

Dengan mengutip al-Qur'an surah an-Nisa' ayat 3, fain khiftum alla ta'dilu fawahidatan, Abduh mengatakan, apabila seorang laki-laki yang tidak mampu memberikan hak-hak istrinya, rusaklah struktur rumah tangga dan terjadilah kekacauan dalam kehidupan rumah tangga tersebut. Sejatinya, tiang utama dalam mengatur kehidupan rumah tangga adalah adanya kesatuan menyayangi antar anggota keluarga. Apakah keadilan kualitatif ini mungkin diwujudkan dan bagaimana pula cara mengukurnya.

Sebagian besar ahli hukum Islam menyadari bahwa keadilan kualitatif ini sesuatu yang sangat mustahil bisa diwujudkan. Abdurrahman Al-Jaziri di dalam kitabnya menuliskan bahwa mempersamakan hak atas kebutuhan seksual dan kasih sayang di antara istri-istri yang dikawini bukanlah kewajiban bagi orang yang berpoligami karena, sebagai manusia, orang tidak akan mampu berbuat adil dalam membagi kasih sayang itu sebenarnya sangat naluriah. Adalah sesuatu yang wajar jika seorang suami hanya tertarik pada salah seorang istrinya melebihi yang lain dan hal yangsemacam ini merupakan sesuatu yang di luar batas kontrol manusia (Abdurrahman Al-Jazizi, 1994, h. 239).

Para ulama fikih tetap bertahan dalam menafsirkan keadilan sebagai syarat poligami pada hal-hal yang bersifat material dan terukur. Hal ini juga menjadikan lebih mudah dilakukan dan poligami menjadi sesuatu lembaga yang bisa dijalankan. Sebaliknya jika keadilan hanya ditekankan pada halhal yang kualitatif seperti cinta, kasih sayang, maka poligami itu sendiri menjadi suatu yang tidak mungkin untuk dilakukan. Berbeda dalam pandangan fikih, poligami yang di dalam kitab-kitab fikih, sebenarnya tidak lagi menjadi persoalan. Tidak terlalu berlebihan jika dikatakan, bahwa ulama sepakat tentang kebolehan poligami, kendatipun dengan persyaratan yang bermacam-macam. As-Sarakhsi menyatakan kebolehan poligami dan mensyaratkan pelakunya harus berlaku adil.

Al-Kasani menyatakan lelaki yang berpoligami wajib berlaku adil tehadap istri-istrinya. As-Syafi'i juga mensyaratkan keadilan di antara para istri, dan menurutnya keadilan ini hanya menyangkut urusan fisik semisal mengunjungi istri di malam atau di siang hari. Memberi syarat yang ketat pada perilaku poligami, para ulama fikih justru memberikan kadar keadilan yang paling rendah, untuk tidak mengatakan bahwa wacana keadilan bukan hal yang sangat penting dan menjadi syarat yang kuat untuk poligami. Jika disederhanakan, pandangan normatif al-Qur'an yang selanjutnya diadopsi oleh ulama-ulama fikih setidaknya menjelaskan dua persyaratan yang harus dimiliki suami.

Pertama, seorang lelaki yang akan berpoligami harus memiliki kemampuan dana yang cukup untuk membiayai berbagai keperluan dengan tambahnya istri yang dinikahi. Kedua, seorang lelaki harus memperlakukan semua istrinya dengan adil. Tiap istri harus diperlakukan 
DE LEGA LATA

Jurnal Ilmu Hukum

FAKULTAS HUKUM UMSU
Pemberian Izin Poligami...(Fitri Rafianti)

Volume 4 Nomor 1, Januari-Juni 2019, 1-15

DOI: https://doi.org/10.30596/dll.v4i1.3167

sama dalam memenuhi hak perkawinan serta hak-hak lain (khairuddin Nasution, 2002, h. 103105). Berkenaan dengan alasan-alasan darurat yang membolehkan poligami, menurut Abdurrahman setelah merangkum pendapat fuqaha, setidaknya ada delapan keadaan.

a. Istri mengidap suatu penyakit yang berbahaya dan sulit disembuhkan

b. Istri terbukti mandul dan dipastikan secara medis tak dapat melahirkan.

c. Istri sakit ingatan.

d. Istri lanjut usia sehingga tidak dapat memenuhi kewajiban sebagai istri.

e. Istri memiliki sifat buruk.

f. Istri minggat dari rumah.

g. Ketika terjadi ledakan perempuan misalnya dengan sebab perang.

h. Kebutuhan suami beristri lebih dari satu, dan jika tidak terpenuhi menimbulkan kemudharatan di dalam kehidupan dan pekerjaanya.

Jelaslah syarat-syarat di atas sangat longgar dan memberikan keleluasaan yang cukup luas pada suami untuk memutuskan apakah ia akan melakukan poligami atau tidak. Jadi titik tekannya pada suami (laki-laki), sesuatu yang dikritik oleh feminis-feminis muslim. Memang dalam pandangan fuqaha, kebolehan poligami tidak lagi diperdebatkan. Beberapa syarat yang melekat pada suami diupayakan untuk diringankan bobotnya. Seperti yang dijelaskan penulispenulis hukum Islam, syarat adil yang sejatinya mencakup fisik dan non fisik, oleh Syafi'i dan ulama-ulama Syafi'iyyah dan orang-orang yang. setuju dengannya, diturunkan kadarnya menjadi keadilan fisik atau material saja. Lebih dari itu, para ulama juga mencoba untuk menggali hikmah-hikmah yang tujuannya adalah untuk melakukan rasionalisasi terhadap praktik poligami.

Al-Jurjani menjelaskan ada empat hikmah yang dikandung poligami. Pertama, kebolehan poligami yang dibatasi sampai empat orang menunjukkan bahwa manusia sebenarnya terdiri dari empat campuran di dalam tubuhnya. Jadi menurutnya, sangatlah pantas laki-laki itu beristri empat. Kedua, batasan empat juga sesuai dengan empat jenis mata pencarian laki-laki; pemerintahan, perdagangan, pertanian dan industi. Ketiga, bagi seorang suami yang memiliki empat orang istri berarti ia mempunyai waktu senggang tiga hari dan ini merupakan waktu yang cukup untuk mencurahkan kasih sayang. Al-Athar sebagaimana yang dikutip oleh Khoiruddin, mencatat empat dampak negatif poligami.

Pertama, poligami dapat menimbulkan kecemburuan di antara para istri. Kedua, menimbulkan rasa kekhawatiran istri kalau-kalau suami tidak dapat bersikap bijaksana dan adil. Ketiga, anak-anak yang dilahirkan dari ibu yang berlainan sangat rawan untuk terjadi perkelahian, permusuhan dan saling cemburu. Keempat, kekacauan dalam bidang ekonomi (Khairuddin Nasution, 1996, h. 100).

Bisa saja pada awalnya suami memiliki kemampuan untuk poligami, namun bukan mustahil suatu saat akan mengalami kebangkrutan, maka yang akan menjadi koban akan lebih banyak. Menarik untuk dianalis bahwa di kalangan ulama fikih terdapat perbedaan pendapat mengenai adil ini. Sebagian melihatnya sebagai syarat yang harus dipenuhi baik sebelum melakukan poligami ataupun sesudahnya, sedangkan sebagian yang lain menempatkan adil sebagai kewajiban suami ketika ia berpoligami. Implikasinya tentu berbeda. Jika adil sebagai 
DE LEGA LATA

Jurnal Ilmu Hukum

FAKULTAS HUKUM UMSU
Pemberian Izin Poligami...(Fitri Rafianti)

Volume 4 Nomor 1, Januari-Juni 2019, 1-15

DOI: https://doi.org/10.30596/dll.v4i1.3167

syarat tidak dipenuhi maka poligami tidak dapat dilakukan, sedangkan jika adil sebagai kewajiban, maka siapapun dapat berpoligami tanpa perlu memeriksa apakah orang tersebut adil atau tidak. Dalam hal ini,KHI menempatkan adil sebagai syarat yang harus dipenuhi suami ketika hendak memperlakukan poligami. Lebih jauh dari itu menurut KHI, jika suami tidak mampu memenuhi persyaratan ini, maka ia tidak diizinkan untuk berpoligami. Untuk itu, adil sebagai syarat untuk berpoligami, oleh KHI harus dapat membuktikan di depan Pengadilan.

Maka dengan demikian, seorang suami harus mampu membuktikan dirinya bahwa dia adalah seorang yang berlaku adil dan tetap akan berlaku adil ketika perkawinan poligami itu berlangsung. Berbeda dengan pandangan ulama klasik, cendekiawan muslim kontemporer sepertinya berbeda dalam menyikapi tentang kebolehan poligami. Musfir Al-Jahrani menyatakan bahwa poligami adalah syarat Islam yang tak terbantahkan keabsahannya. Kendatipun syariat tidak mewajibkan, namun al-Qur'an membolehkannya. Siapa saja yang menolak poligami sebenarnya satu sikap yang pro Barat dan menolak kehujjahan al-Qur'an. Padahal kebolehan poligami di dalam al-Qur'an adalah untuk kemaslahatan di dunia dan di akhirat. Karenapoligami bertujuan untuk memelihara hak-hak wanita dan memelihara kemuliannya (Musfir Al-Jahrani, 1996, h. 38-39).

Senada dengan al-Jahrani, Immanuddin Husein juga berpendapat bahwa poligami dibolehkan di dalam al-Qur'an, bahkan di dalam penyariatan poligami tidak hanya terkandung hikmah tetapi lebih dari itu ada pesan-pesan strategis yang dapat diaktualisasikan untuk kebahagiaan manusia. Tambahnya, bahwa poligami memiliki nilai sosial ekonomi untuk mengangkat harkat dan martabat wanita. Untuk itulah Islam hanya mensyariatkan poligami lengkap dengan adab yang harus dijungung tinggi bagi setiap laki-laki yang akan berpoligami. Husein juga mengecam orang-orang yang menolak poligami.M. Quraish Shihab setelah mengkaji dan menganalisa surah an-Nisa' ayat/4:3 menyimpulkan tentang kebolehan poligami dan kebolehannya dapat diberlakukan dalam kondisi darurat dengan persyaratan yang cukup berat (Imaruddin Husein, 2003: 85-106).

Muhammad 'Abduh berpendapat bahwa poligami merupakan tindakan yang tidak boleh dan haram (M. Quraish Shihab, 1996, h. 199). Poligami hanya dibolehkan jika keadaan benar-benar memaksa seperti istri tidak dapat mengandung. Kebolehan poligami juga mensyaratkan kemampuan suami untuk berlaku adil. Dan ini merupakan sesuatu yang sangat berat, seandainyapun manusia tetap bersikeras untuk berlaku adil tetap saja ia tidak akan mampu membagi kasih sayangnya secara adil.

Abdul sebenarnya ingin mengatakan, asas perkawinan Islam adalah monogami. Menurut Muhammad Asad seperti yang dikutip Asghar menyatakan, "Berkaitan dengan izin untuk kawin lebih dari satu istri, (hingga maksimum empat), hal tersebut sangat dibatasi dengan syarat, "jika kamu punya alasan untuk takut, kamu mungkin tidak mampu untuk memperlakukan mereka dengan adil yang sama maka kawinlah satu, karena untuk membuat perkawinan majemuk seperti itu, hanya sangat mungkin dalam kasus-kasus yang luar biasa dan di bawah keadaan-keadaanyang luar biasa. 
DE LEGA LATA

Jurnal Ilmu Hukum

FAKULTAS HUKUM UMSU
Pemberian Izin Poligami...(Fitri Rafianti)

Volume 4 Nomor 1, Januari-Juni 2019, 1-15

DOI: https://doi.org/10.30596/dll.v4i1.3167

Selanjutnya menurut Maulana Muhammad Ali ketika menafsirkan surah An-Nisa': 3 menyatakan: "Bagian ini membolehkan poligami dalam keadaan tertentu"; ayat tersebut tidak memerintahkan poligami, bahkan tidak juga mengizinkan poligami tanpa ada syarat tertentu. Bisa dicatat di sini bahwa penjelasan bagian ini secara umum dipahami adalah berdasarkan laporan yang dimuat dalam sahih muslim. Menurut yang dipahami Aisyah, ayat ini mempunyai arti bahwa jika para wali anak-anak yatim takut mengawini mereka, para wali tersebut tidak dapat berlaku adil kepada anak-anak yatim tersebut maka mereka harus mengawini perempuan lain... kita beri tahu bahwa jika mereka tidak dapat berbuat adil kepada anak-anak yatim, maka mereka boleh mengawini para janda, yang anaknya, dengan demikian akan menjadi anak mereka sendiri, dank arena jumlah perempuan itu lebih besar dibanding laki-laki, mereka diizin untuk mengawini bahkandua, tiga atau empat perempuan.

Dengan demikian jelaslah bahwa izin untuk beristri lebih dari satu diberikan dalam keadaan tertentu pada masyarakat Islam yang ada pada waktu itu. Tindakan Nabi dalam mengawini para janda, demikian juga contoh dari banyak sahabatny, menguatkan pernyataan ini. Kawin dengan gadis yatim juga didukung karena ada kesulitan-kesulitan sama yang dihadapi oleh para gadis yatin dan para janda". Para mufassir yang telah disebut di atas, sepakat kebolehan poligami hanyalah dalam keadaan yang luar biasa dan benar-benar luar biasa.

Di samping itu keharusan berlaku adil adalah syarat yang tidak bisa ditawar-tawar bagi orang yang melakukan poligami. Lebih dari itu semua, motivasi poligami, kendati tidak memungkiri hal-hal yang bersifat biologis, haruslah mengutamakan motivasi social untuk membantu para janda dengan anak-anaknya serta gadis-gadis yatim yang membutuhkan pertolongan. Amina Wadud Muhsin adalah jenis feminis muslim yang menolak poligami terlebih lagi jika dihubung-hubungkan dengan alasan normatif teologis. Baginya tidak ada satu argumenpun yang dapat menyatakan poligami abash untuk dilakukan, termasuk yang menyandarkan argumentasinya pada al-Qur'an. Menurutnya, tiga alasan yang sering dikemukakan sebenarnya sama sekali tidak didukung oleh al-Qur'an; pertama, finansial; dalam menghadapi persoalan ekonomi seperti pengangguran, pria yang mampu sebaiknya menghidupi lebih dari seorang istri.

Sehingga jelas wanita dipandang sebagai beban finansial; bisa bereproduksi tapi tidak produktif. Tapi saat ini argumentasi ini tidak dapat lagi digunakan, karena sudah banyak wanita yang mampu bekerja dan tidakmemerlukan dukungan pria. Malah dalam tingkat tertentu, peluang wanita untuk bekerja jauh lebih besar ketimbang pria. Kedua, alasan yangdikemukakan adalah karena si istri tidak memiliki anak. Alasan ini sebenarnya juga digunakan oleh UUP dan KHI. Padahal tidak satu ayatpun yang menyatakan alasan ini dapat digunakan sebagai alasan poligami. Kendatipun keinginan memiliki anak sesuatu yang alamiah, maka cara mengasuh anak-anak yatim dan terlantar adalah cara yang dibenarkan alQur'an bukan dengan melakukan poligami. Ketiga, poligami bukan hanya tidak tercantum dalam al-Qur'an, tetapi jelas merupakan tindakan non Qur'ani, yang beruapaya mendukung nafsu yang tak terkendali kaum pria; jika kebutuhan seksual seorang pria tidak dipenuhi 
DE LEGA LATA

Jurnal Ilmu Hukum

FAKULTAS HUKUM UMSU
Pemberian Izin Poligami...(Fitri Rafianti)

Volume 4 Nomor 1, Januari-Juni 2019, 1-15

DOI: https://doi.org/10.30596/dll.v4i1.3167

dengan seorang istri, ia memiliki dua istri (Amina Wadud Muhsin, 1994, h. 113-114).

Bagaimanapun poligami tetap akan diperdebatkan. Sebenarnya masalahnya tidak terlalu berat dan tidak perlu menempatkannya sebagai sesuatu yang membahayakan bagi kehidupan perempuan, sehingga harus ditolak secara a priori. Pokoknya, poligami merupakan syari'at agama yang keberadaannya jelas di dalam al-Qur'an, terlepas bagaimana ayat tersebut diterapkan. Tinggal lagi masalahnya dalam kondisi yang bagaimana dan oleh siapa syari'at poligami itu dapat dilaksanakan. Jika seseorang memiliki kesanggupan dan beristri lebih dari satu merupakan kebutuhan dirinya agar tetap dapat memelihara muru'ah, dimotivasi untuk membantu dan dapat berlaku adil, maka ia boleh melakukan poligami. Sebaliknya orang yang tidak memiliki syarat-syarat yang pantas, maka poligami merupakan sesuatu yang harus dihindari. Dengan demikian, poligami merupakan sesuatu yang sangat pribadi dan kondisional.

Sungguh tidak tepat jika poligami digeneralisir, seolah-olah poligami syari'at yang berlaku umum dandapat dilaksanakan oleh semua orang. Selanjutnya menukil Parvez, Asghar menulis, untuk poligami diperlukan persetujuan istri pertama, yang bertujuan untuk perlakuan yang adil. Untuk memutuskan apakah seorang laki-laki memenuhi syarat sosial untuk poligami atau tidak adalah wewenang negara, bukan individu. Karena itu, negaralah yang menetapkan lewat perundang-undangan dengan mempertimbangkan kondisi sosialnya. Karena itu, untuk mengetahui asas perkawinan dalam Islam harus dikupas seluruh nash yang berhubungan dengan perkawinan, melalui minimal metode tematik, atau, lebih dari itu, metode holistik, atau kombinasi keduanya.

Adapun terhadap nash poligami, an-Nisā' (4): 3, yang seharusnya dalam pembahasannya juga dihubungkan dengan ayat sebelumnya, an-Nisā' (4): 1-2 dan ayat sesudahnya, an-Nisā' (4): 129, menunjukkan bahwa ada kondisi tertentu untuk kebolehan poligami. Karena itu, nash ini masuk kelompok nash kasuistik yang temporal sifatnya untuk menjawab masalah yang ada ketika itu, yakni keengganan para wali mengembalikan harta anak yatim yang ada di bawah perwalian mereka sesudah cukup umur (dewasa). Dengan menjadikan ayat-ayat tersebut menjadi satu kesatuan yang utuh dalam pembahasan, dari teks yang ada anNisā' (4): 3 jelas bahwa Quran berbicara poligami hubungannya dengan konteks pengasuhan anak yatim wanita yang sudahcukup umur, sementara walinya enggan mengembalikan harta tersebut kepada para anak yatim dimaksud.

Sebagai jalan keluar, para wali dianjurkan menikahi wanita tersebut agar mereka boleh terus menggunakan harta yang ada di bawah perwaliannya. Dengan demikian menjadi jelas bahwa an-Nisā' (4): 2 menjelaskan problem yang dihadapi ketika itu, dan anNisā' (4): 3 merupakan jawaban terhadap masalah spesifik tersebut. Jawaban yang diberikan adalah, para laki-laki yang menjadi wali dapat menikahi para wanita yatim yang sudah cukup umur yang ada di bawah perwaliannya maksimal empat. Tindakan ini dimaksudkan sebagai tindakan kejahatan paling kecil daripada menggunakan harta para anak yatim tersebut dengan jalan yang tidak halal. Tentu saja al-Quran membuat syarat untuk bolehnya poligami tersebut, yakni harus dapat berlaku adil. 
DE LEGA LATA

Jurnal Ilmu Hukum

FAKULTAS HUKUM UMSU
Pemberian Izin Poligami...(Fitri Rafianti)

Volume 4 Nomor 1, Januari-Juni 2019, 1-15

DOI: https://doi.org/10.30596/dll.v4i1.3167

Setelah diberikan peringatan, bahwa kalau tidak dapat berlaku adil cukup satu saja, kemudian disebutkan bahwa kamu tidak akan dapat berlaku adil. Karena itu, minimal jangan terlalu condong kepada salah satu atau sebagian yang mengakibatkan yang lain terabaikan anNisā' (4): 129. Dengan ungkapan lain, karena keengganan untuk mengembalikan harta anak yatim yang cukup umur, Quran menyelesaikan dengan jalan boleh menikahi lebih dari satu dan maksimal empat, dengan syarat jangan terlalu condong kepada salah satu atau sebagian yang mengakibatkan yang lain terabaikan. Sebab untuk berbuat adil jelas tidak mungkin dilakukan (Fazlur Rahman, 1982, h. 299)

Praktek Nabi SAW yang berhubungan dengan asas perkawinan, adalah bahwa selama dua puluh lima tahun,perkawinan pertama Nabi dengan Khadijah adalah monogami. Setelah meninggal baru beliau menikahi wanita-wanita lain, terutama karena alasan sosial dan dakwah Islam. Dengan demikian, dengan an-Nisā' (4): 3 ini, Quran memberikan kemungkinan poligami, yakni dengan alasanalasan dan kondisi-kondisi atau syarat-syarat tertentu. Alasanalasan dan kondisi-kondisi tertentu ini barangkali berhubungan dengan tujuan perkawinan dan atau kebutuhan masyarakat, dan barangkali poligami dianggap masih lebih baik daripada perceraian, maka muncullah alasan kebolehan melakukan poligami, yakni di antaranya: (1) istri mandul (2) istri tidak mampu melayani kebutuhan seksual suami, bukan demi kepuasan, tetapi demi kemanusiaan, (3) istri ditahan dalam waktu lama, (4) berlebihan wanita dalam masyarakat. Kaitannya dengan kebutuhan masyarakat misalnya, karena jumlah wanita lebih banyak dari kaum pria. Sementara kalau monogami dipertahankan akan memicu munculnya praktek pelacuran (prostitusi).

Di samping itu, ada juga ayat-ayat lain yang berhubungan dengan perkawinan yang perlu dicatat, misalnya ayat yang mengisyaratkan pentingnya menjaga hubungan perkawinan an-Nisā' (4): 1959, pentingnya perkawinan an-Nisā' (4): 160, ar-Rũm (30): 2161, an-Nahl (16): 72, an-Nisā' (4): 2562, dan 59 "Dan bergaullah dengan mereka secara patut, kemudian bila kamu tidak menyukai mereka, (maka bersabarlah) karena mungkin kamu tidak menyukai sesuatu, Padahal Allah menjadikan padanya kebaikan yang banyak." 60 "Dan bertakwalah kepada Allah yang dengan (mempergunakan) nama-Nya kamu saling meminta satu sama lain". 61 "Allah menjadikan bagi kamu isteri-isteri dari jenis kamu sendiri dan menjadikan bagimu dari isteri-isteri kamu itu, anak-anak dan cucu-cucu". 62 "Dan barangsiapa di antara kamu (orang merdeka) yang tidak cukup perbelanjaannya untuk mengawini wanita merdeka lagi beriman, ia boleh mengawini wanita yang beriman, dari budak-budak yang kamu miliki." Anjuran perkawinan an-Nũr (24); 32 s/d 3363. Demikian juga betapa erat hubungan antara suami dan istri disyaratkan dalam al-Baqarah (2): 187. Ungkapan ini bukan hanya mengisyaratkan bahwa suami istri saling membutuhkan, lebih dari itu, mereka berdua, yang masing-masing menurut kodratnya memiliki kekurangan, harus dapat berfungsi 'menutup kekurangan pasangannya.

\section{Sanksi Poligami}

Pembahasan mengenai sanksi poligami dilihat dari sudut doktrin hukum Islam 
Jurnal Ilmu Hukum FAKULTAS HUKUM UMSU
Pemberian Izin Poligami...(Fitri Rafianti)

Volume 4 Nomor 1, Januari-Juni 2019, 1-15

DOI: https://doi.org/10.30596/dll.v4i1.3167

konvensional setidaknya memerlukan dua segi tinjauan: pertama, konsep sanksi itu sendiri; kedua, status hukum poligami. Segi yang pertama diarahkan pada kajian hukum jinayat (pidana Islam), sementara segi yang kedua ditinjau dari kajian tafsir nas dan pandangan mazhab fikih. Identifikasi kedua sudut tersebut penting diungkapkan dalam rangka memahami seberapa jauh langkah kriminalisasi poligami punya keterkaitan atau tidak dengan doktrin hukum konvensional.

Dalam kajian hukum jinayah, dilihat dari segi kualitas dan kuantitas sanksi hukum ('uqubat), fuqaha umumnyamengklasifikasikan tindak pidana (jarimah) kepada tiga bagian: pertama, jarimah hudud; kedua, jarimah qishash-diyat; ketiga, jaramah ta'zir (Abdurrahman al-Jaziri, 1999, h. 12). Berikut ini gambaran umum mengenai ketiga kategori tersebut: Kategori pertama, hudud (bentuk jamak dari kata had), adalah jenis hukuman yang bentuk dan ukurannya telah ditetapkan (oleh syara'), terkait dengan hak Allah atau demi kemaslahatan umum.

Mengenai bentuk-bentuk tindak pidana yang dikategorikan sebagai jarimah hudud ada tujuh macam, yaitu: (Abd al-Qadir 'Audah, 1997, h. 634).
a. Perzinahan,
b. Melakukan tuduhan zina,
c. Mengonsumsi minuman keras,
d. Pencurian,
e. Perampokan,
f. Pindah agama, dan
g. Pemberontakan

Menurut catatan Wahbah az-Zuhaili, mengenai bentuk - bentuk tindak pidana yang dikategorikan sebagai jarimah hudud terdapat perbedaan pendapat di kalangan ulama. Menurut kalangan jumhur ulama jarimah hudud mencakup tujuh macam tindak pidana, yaitu
a. pencurian;
b. perzinahan;
c. penggunaan minuman khamar;
d. penggunaan sesuatu yang berefek memabukkan non-khamar;
e. tuduhan zina palsu (qazf)
f. qishash;
g. riddah (pindah agama).

Sedangkan kalangan Hanafiyah hanya mengintrodusir 5 macam jarimah hudud dengan tidak memasukkan dua kategori terakhir sebagai bagian dari jarimah hudud. Perbedaan ini muncul antara lain dilatarbelakangi perbedaan terminologis yang digunakan kedua pihak. Kalangan jumhur mendefinisikan had sebagai hukuman (uqubah) yang telah ditentukan (bentuk dan ukurannya) oleh syarak, baik yang terkait dengan hak Allah maupun hak hamba (manusia). Sedangkan kalangan Hanafiyahmendefinisikan ¥ad sebagai hukuman yang telah ditentukan oleh Allah sehingga tak seorang pun boleh menepikannya, dan ialebih terkait pada hak-hak Allah (Wahbah az-Zuhaili, 1997, h. 5275). Adapun kategori kedua, qishash-diyat, 
DE LEGA LATA

Jurnal Ilmu Hukum

FAKULTAS HUKUM UMSU
Pemberian Izin Poligami...(Fitri Rafianti)

Volume 4 Nomor 1, Januari-Juni 2019, 1-15

DOI: https://doi.org/10.30596/dll.v4i1.3167

mencakup tindak pidana: pembunuhan dengan sengaja, pembunuhan semi sengaja, pembunuhan yang keliru, penganiayaan secara sengaja, penganiayaan yang keliru.

Bentuk sanksi hukum bagi tindak pidana qishash-diyat, secara variatif, meliputi: qishash-diyat, kafarat, terhalang dari hak waris, terhalang dari hak wasiat.Kategori ketiga adalah pidana ta'zir, suatu tindak pidana berupa perbuatan maksiat atau jahat yang dikenai sanksi hukuman yang tidak ditentukan oleh syara' (non-had dan non-kaffarat), baik yang berkaitan dengan hak Allah maupun hak hamba. Dengan kata lain hukuman ta'zir adalah hukuman yang dijatuhkan pada perbuatan jinayah selain kedua kategori di atas (jarimah hudud dan jarimah qishash-diyat). Kebijakan pidana ta'zir sendiri merupakan otoritas ulul amri (pemerintah/yudikatif) dimana bentuk sanksi hukumannya pun beragam bisa berupa pemukulan, penahanan (kurungan/pemenjaraan), teguran/peringatan, dan bentuk hukuman lainnya sesuai dengan pertimbangan kontekstua.

Malah sebagian ulama, kalangan Hanafiyah dan Malikiyah,membolehkan penjatuhan hukuman mati terhadap tindak pidana yang dilakukan berulang kali atau sadis, homo seksual, pelecehan agama/simbol agama, perbuatan sihir (santet), dan perbuatan zindiq (Wahbah azZuhaili, 1997, h. 5592). Semua langkah hukum ini diletakkan dalam kerangka siyasah berdasarkan pertimbangan hakim mana yang dipandang lebih maslahat (tepat).Sedangkan, kalangan Malikiyah dan Hanabilah juga memasukkan perbuatan spionase dan bid'ah dalam kategori ta'zir yang dapat dijatuhi hukuman mati. Adapun mengenai jenis tindak pidana yang dapat dikenai ancaman hukuman kurungan/penjara, dalam hal ini, ulama berbeda pendapat. Kalangan Hanafiyah menetapkan hukuman kurungan/penjara dapat dikenakan pada semua jarimah ta 'zir. Sedangkan jumhur ulama berpendapat bahwa hukuman tersebut tidak berlaku pada semua jarimah ta'zir.

Menurut mereka hanya 8 (delapan) tindak pidana yang dapat dikenai hukuman kurungan/penjara, yaitu: (Wahbah az-Zuhaili, 1997, h. 5594)

a. Percobaan pembunuhan;

b. Pelarian diri oleh budak;

c. Pengingkaran penunaian kewajiban;

d. Pengakuan palsu atas kebangkrutan;

e. Perbuatan maksiat;

f. Keengganan melaksanakan kewajiban sebagai muslim yang tidak dapat diwakilkan;

g. Pengakuan kepemilikan secara paksa;

h. Keengganan melakukan kewajiban ibadah (hak Allah) yang tak dapat diwakilkan.

Di dalam hal dapat diberlakukan tidaknya hukuman denda, para ulama juga berbeda pendapat. Sebagian ulama tidak membolehkannya dengan alasan hal itu sama dengan pengambilan harta secara zalim. Sedangkan Abu Yusuf, ImamMalik ibn Anas, Imam Syafi‘i (salah satu qaul-nya), dan Imam Ahmad ibn Hanbal membolehkannya berdasarkan praktik yang pernah dilakukan oleh Rasulullah dan sahabatnya, Khalifah Umar ibn Khatthab dan Khalifah Ali ibn Abi Talib, sedangkan mengenai hukuman fisik (berupa pemukulan misalnya) ulama sepakat membolehkannya berdasarkan praktik yang pernah diterapkan oleh Rasulullah 
Jurnal Ilmu Hukum

FAKULTAS HUKUM UMSU
Pemberian Izin Poligami...(Fitri Rafianti)

Volume 4 Nomor 1, Januari-Juni 2019, 1-15

DOI: https://doi.org/10.30596/dll.v4i1.3167

dan Khulafa' ar-Rasyidin, meskipun dalam hal ketentuan dan batas maksimalnya terdapat perbedaan pendapat.

Berdasarkan uraian di atas dapat dipahami bahwa poligami, jika dilihat dari kategori dan bentuk hukum pidana Islam di atas, bukanlah termasuk tindak pidana kategori pertama (Hudud) dan juga tidak termasuk kategori kedua (qishshashdiyat). Jika demikian, dapat disimpulkan bahwa hanya ada satu kemungkinan bahwa poligami lebih cenderung diposisikan dan dilihat dalam wilayah kategori ketiga, yaitu tindak pidana ta'zir, dimana peran politik hukum (siyasah) memerankan peran dominan dalam penentuan kategori dan bentuknya. Dari sudut tinjauan ini, secara teoritis, dapat dikatakan bahwa sanksi poligami tetap relevan dengan doktrin hukum Islam konvensional, khususnya yang terkait dalam wilayah jinayah.

\section{KESIMPULAN DAN SARAN Kesimpulan}

Bahwa poligami secara yuridis telah diatur dengan tegas dalam hukum keluarga Islam, Dibanding dengan pendapat imam mazhab fiqh, hukum keluarga Islam di Indonesia dinilai lebih substantif dalam mengatur praktik poligami. Hal ini terlihat pada prosedur pengajuan izin poligami pada Pengadilan Agama (Mahkamah Syari'ah), penentuan alasan-alasan dan syarat-syarat yang harus ada untuk berpoligami serta adanya sanksi bagi seseorang yang melanggar aturan poligami. Hal ini lebih jelasnya dapat dilihat secara eksplisit, peraturan perundang-undangan yang mengatur tentang poligami di negara Indonesia

Di dalam Hukum Islam di Indonesia tidak mengenal adanya pengabsahan poligami yang dilakukan tanpa izin Pengadilan Agama. Persyaratan Poligami Perundang-undangan Perkawinan Indonesia tentang Poligami telah berusaha mengatur agar laki-laki yang benarbenar mampu secara ekonomi menghidupi dan mencukupi seluruh kebutuhan (sandangpangan-papan) keluarga (istri-istri dan anak-anak), serta mampu berlaku adil terhadap istriistrinya sehingga istri-istri dan anakanak dari suami poligami tidak disia-siakan, Pada sisi lain peranan Pengadilan Agama untuk mengabsahkan praktik poligami menjadi sangat menentukan bahkan dapat dikatakan satu-satunya lembaga yang memiliki otoritas untuk mengizinkan poligami.

Sanksi poligami di Indonesia, orang yang melanggar aturan poligami adalah melanggar peraturan yang berlaku, dan dapat dihukum dengan hukuman denda setinggi-tingginya $\mathrm{Rp}$ 7.500,-, sedangkan PNS yang beristri lebih dari seorang tanpa izin, dapat dihukum dengan empat kemungkinan: Penurunan pangkat setingkat lebih rendah; Pembebasas jabatan; Pemberhentian dengan hormat tidak atas permintaan sendiri sebagai PNS; pemberhentian dengan tidak hormat sebagai PNS. Selain itu, bagi PNS wanita yang menjadi istri kedua/ketiga/keempat dari seorang pria dihukum dengan hukuman diberhentikan tidak dengan hormat sebagai Pegawai Negeri Sipil.

\section{Saran}

Pengaturan mengenai poligami pada pengadilan agama di Indonesia sudah jelas dan bagus, dilihat dengan adanya persyaratan yang harus dipenuhi seorang laki-laki jikalau ia ingin 
melakukan poligami, salah satu syaratnya adalah ia harus dinilai mampu secara ekonomi untuk menghidupi dan menyediakan kebutuhan istri-istri dan anak-anaknya. Tetapi mungkin saran agar dapat dimasukan dalam salah satu persyaratan juga agar pengadilan agama harus melihat dan menilai alasan seorang laki-laki ingin berpoligami agar tidak terjadi kemungkinan buruk dikemudian hari. 


\section{DAFTAR PUSTAKA}

Audah, Abd al-Qadir. (1997). at-Tasyr ‘ al-Jina'i al-Islami Muqaranan bi al-Qan-n alWa. Beirut: Mu'assat ar-Risalah.

Al-Jarjawi, Ali Ahmad. (1994). Hikmah al-Tasyri' wa Falfasatuhu. Beirut: Dar alFikr.

Al-Jazizi, Abdurrahman. (1999). Kitab al-Fiqh 'ala al-Mazahib al-Arba'ah. jld. V. Beirut: Dar al-Kutub al-'Ilmiyyah.

az-Zuhaili, Wahbah. (1984). al-Fiqh al-Islami wa Adillatuh, juz VII. Damascus: Dar al-Fikr.

Fazlur Rahman. (1982). The status of Women in Islam: A Modernist Interpretation”, dalam The Saparate Worlds: Studies of Purdah in South Asia, ed. Hanna Papanek and Gail Minault. Delhi: Chanakya Publication.

Husein, Imaruddin. (2003). Satu Istri Tak Cukup. Jakarta: Khazanah.

Muhsin, Amina Wadud. (1994). Wanita di dalam Al-Qur'an. Bandung: Pustaka Salman.

Musfir Al-jahrani. (1997). Poligami dalam berbagai persepsi,penerjemah Moh.Suten Ritonga. Gema Insani Press: Jakarta.

Nasution, Khairuddin. (1996). Riba dan Poligami: Sebuah Studi atas Pemikiran Muhammad Abduh. Yogyakarta: Pustaka Pelajar.

Nasution, Khairuddin. (2002). Status wanita di Asia Tenggara; Stufi terhadap Perundangundangan Perkawinan Muslim Kontemporer di Indonesia dan Malaysia. Jakarta: INIS.

Shihab, M. Quraish. (2002). Wawasan Al-Qur'an; Tafsir Mudhu'I, atas Pelbagai Persoalan Umat. Bandung: Mizan. 